\title{
Living life in the face of loss: parenteral nutrition in ovarian cancer patients in bowel obstruction
}

A.M. Sowerbutts ${ }^{1}$, S. Lal ${ }^{2}$, J. Sremanakova ${ }^{1}$, A. Clamp ${ }^{3}$, G.C. Jayson ${ }^{3}$, A. Teubner ${ }^{2}$, L. Hardy ${ }^{4}$, C. Todd ${ }^{1}$, A.-M. Raftery ${ }^{5}$,

E. J. Sutton ${ }^{6}$, R. Morgan ${ }^{3}$, A. J. Vickers ${ }^{3}$, S. Burden ${ }^{1}$

${ }^{1}$ Division of Nursing Midwifery and Social Work, School of Health Sciences, The University of Manchester ${ }^{2}$ Intestinal Failure Unit, Salford

Royal NHS Foundation Trust ${ }^{3}$ Division of Cancer Services, The Christie NHS Foundation Trust ${ }^{4}$ Dept of Nutrition \& Dietetics, Manchester

University NHS Foundation Trust, ${ }^{5}$ Supportive/Palliative Care Team, The Christie NHS Foundation Trust, ${ }^{6}$ Population Health Sciences,

Bristol Medical School, University of Bristol

\section{Rationale}

- Malignant bowel obstruction (MBO) is a complication of advanced ovarian cancer and is often inoperable

- These patients may receive home parenteral nutrition (PN)

- This research investigated:

- The experiences of women and their family caregivers of home PN

- Patient nutritional status and survival

\section{Methods}

- A mixed methods study involving 38 women with ovarian cancer and inoperable bowel obstruction admitted to tertiary cancer centre between October 2016 and December 2017.

Patient characteristics and survival data were collected from medical records. Body composition was measured using computed tomography scans. ${ }^{1}$

- 92 longitudinal in-depth interviews with 20 women, 13 relatives and healthcare professionals.

- Interviews were transcribed verbatim and analysed thematically influenced by the techniques of Van Manen ${ }^{2}$ using NVivo 10.

- Data were read and re-read themes and subthemes were created inductively from the data.

- Anonymous quotations have been used to illustrate each theme and give an overview of the data.

\section{Results}

\section{CONSORT DIAGRAM}

38 patients MBO
$\int 6$ no PN

32 patients $\mathrm{PN}$ on ward

4 Died

4 End of life

4 Decline

3 Unsuitable

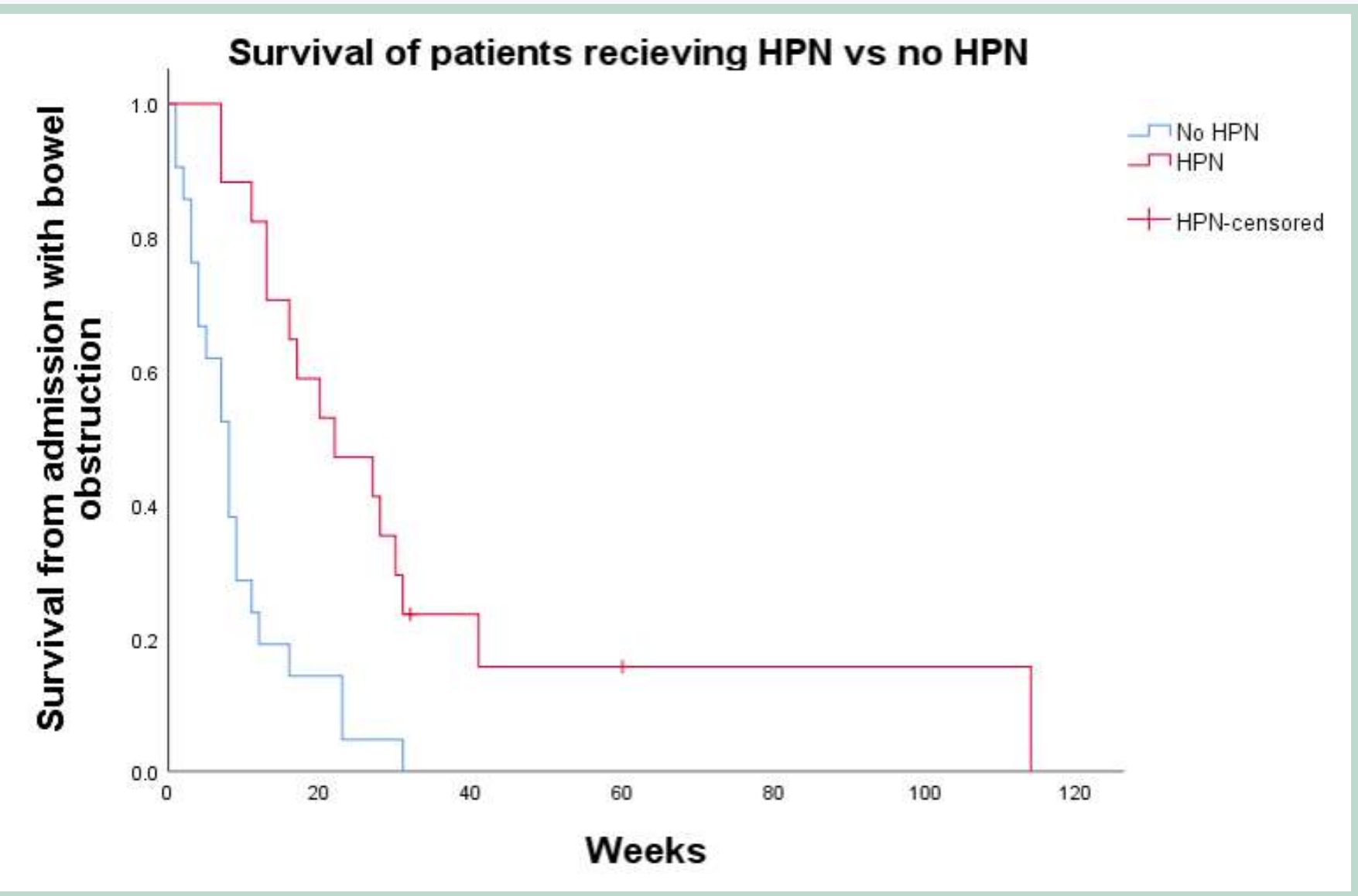

\begin{tabular}{|l|c|}
\hline Patient characteristics \\
\hline Mean age $\mathrm{N}=38$ & 67 years (SD7.5) \\
\hline Histology $\mathrm{N}=38$ & 31 \\
\hline Serous & 1 \\
\hline Endometrial & 2 \\
\hline Clear cell & 2 \\
\hline Adenocarcinoma NOS & 1 \\
\hline Carcinosarcoma & 1 \\
\hline Mucinous & 34 \\
\hline Degree of MBO N = 38 & 3 \\
\hline Multilevel obstruction & 1 \\
\hline Single obstruction & \\
\hline Missing data & 14 \\
\hline $\begin{array}{l}\text { Lines of chemotherapy } \\
\text { following MBO N=38 }\end{array}$ & 19 \\
\hline No chemotherapy & 5 \\
\hline 1 line chemotherapy & $21 \mathrm{~kg}(\mathrm{SD} 5.86)$ \\
\hline 2 lines chemotherapy & $31 \mathrm{~kg}(\mathrm{SD} 2.88)$ \\
\hline Mean fat mass $\mathrm{n}=33$ & \\
\hline $\begin{array}{l}\text { Mean muscle mass } \\
\mathrm{n}=33\end{array}$ & \\
\hline
\end{tabular}

\begin{tabular}{|c|c|}
\hline \multicolumn{2}{|l|}{ Patient outcomes } \\
\hline $\begin{array}{c}\text { Median survival from } \\
\text { MBO } n=38\end{array}$ & $\begin{array}{c}70 \text { days } \\
\text { (range } 8-506 \text { ) }\end{array}$ \\
\hline $\begin{array}{c}\text { Median time on home } \\
\text { PN } n=17\end{array}$ & 91 days \\
(range $6-441)$ \\
\hline
\end{tabular}

\section{Losses}

- Curtailment of activities of daily living

- "I can't stand anybody eating...in front of me. It is a real problem."

- Limiting bodily freedom "All the wires get tangled"

- Imposed routine "They come too early in the afternoon" "I am physically falling to bits"

- Survival Gains
- "If I wasn't on this, I wouldn't be
here."
- "This is important, this is my lifeline"
- Quality of life
- Improved as patients could fed at
- "It's nice to have your own things
around you."

\section{Discussion}

- Patients and families saw PN as a life line and were grateful for it.

- However, this benefit came with losses.

- Healthcare professionals need to be realistic about these.

- Nevertheless, patients will suffer losses to continue living.

\section{References}

1.Mourtzakis $\mathrm{M}$ et al: A practical and precise approach to quantification of body composition in cancer patients using computed tomography images acquired during routine care. Applied Physiology, Nutrition, and Metabolism 2008, 33(5):9971006

2.Van Manen, M. (1990). Researching lived experience: Human science for an action sensitive pedagogy. Ont: Althouse Press.

\section{Acknowledgements}

We would like to thank all the patients and family caregivers who gave generously of their time. We are grateful for Marie Curie for funding this study.

MANCHESTER 